\title{
Ideology and Subversion: A Comparative Study of Mrinal Sen's Padatik and Raghav Bandopadhyay's Communis
}

\author{
Pratyusha Pramanik ${ }^{1}$ \\ https://orcid.org/0000-0001-8854-5504 \\ ${ }^{1}$ Indian Institute of Technology (BHU), Varanasi.
}

\begin{abstract}
Padatik, the final part of Mrinal Sen's movies of the Calcutta Trilogy, offers both a historical document on the political mindset of the burgeoning Bengali youth and a personal struggle of Sen himself making sense of the Marxist revolutionary ideology and ascertaining whether or not it is a misguided enterprise. Raghav Bandyopadhyay in his conversation with Dipesh Chakrabarty recollects how during his prison days he had sent a letter to the regional comrades. He had enlisted the reasons why their project had failed, also stating, how it would be best to abort the mission and retreat to "safer shelters" to study and reconsider the struggle. His years as a political activist and a political prisoner were penned down as Communis (1975). This paper is a comparative study of the picture of the 1970s Calcutta that Sen and Bandyopadhyay present in Padatik and Communis respectively, with special attention to the youth upsurge and the violent mission that the contemporary youth had dedicated themselves to. Bandyopadhyay, through his words, paints an equally realistic portrait of the "infernal city" that Sen films in his Trilogy. While Bandyopadhyay has largely been an unsung hero in the canonical growth of Indian Literature, Sen has been a world phenomenon with his brand of parallel cinema. However, both of them offer criticism to the left movement, when it was lying low and was in disarray. The paper would thus assess both their differences and their similarities in their reception and representation of the movement, its ideology, and its subversion.
\end{abstract}

Keywords: Calcutta, Marxism, Ideology, Communist Movement, Conscientization.

\section{Introduction}

What is it to be a Communist? Is it to be like AB of Raghav Bandopadhyay's Communis, or Nikhil of Mrinal Sen's movie Padatik - party leaders with unquestionable orthodox policy embodying the theories of Marx, Lenin, Mao without any ability to be ingenuously revolutionary? Or is it to be like Biman of Padatik or Suku, Biru, Montu of Communis- workers,

This open-access work is licensed under a Creative Commons Attribution Noncommercial 4.0 International License. For more information visit https://creativecommons.org/licenses/by-nc/4.0/ 
peasants, and petty bourgeoisie, often unequipped with theories but functioning on revolutionary passion, and blind obedience to a leader who has promised them a revolution? Or is it to be like Minu or Shilpi, who do not know much about class struggle or revolution, but are struggling for a personal loss? Or is it to be like Gora and Sumit, who have their theories and know the social situation, but also feel the urge to raise a question, when things do not seem right? The term Communist over here is not used to address just the members of the Communist party. Communists or the subaltern mispronunciation "communis" of the 1970s Bengal were intellectuals with a specific public role to play. They were not just engineering a revolution, but they had taken upon themselves the responsibility of questioning the existing social structure. Within the revolution there were ranks for the party workers - there were industrial laborers, farmers, college and university students, etc. This hierarchy of ranks was, however, very similar to the existing social structure, which the Communists were critiquing. Although leaders like Charu Mazumdar had instructed the student and youth leaders to integrate the peasants and to learn from the peasants (Mazumdar). However, the urban intelligentsia was not always able to learn from the struggles and experiences of the peasants- they failed to bridge the existing caste and class gap. Both these groups shared their common hatred for existing hierarchy and authority, the violence that erupted in the cities and villages alike, were not always targeted against class enemies. The violence and loss of life antagonized the people in general against the revolution. This in turn helped the State to police the movement and force several leaders to surrender (Banerjee; Ray). It is very difficult to differentiate between revolutionaries and fascists, the difference is only defined when sufficient self-criticism is performed and the movement is looked at in hindsight. In this context Foucault's (x-xiii) question- how does one keep from being a fascist, even and especially when one believes oneself to be a revolutionary 
militant? -remains pertinent. Of the several pieces of literature that were produced on the Naxalite movement in the following decades, many tended to contemplate the trajectory of the movement and questioned what went wrong (Banerjee; Ray). Several of these accounts were by party sympathizers or former revolutionaries. The party amidst this went through several factions on account of the difference of opinions among different party leaders- a reason behind this factionalism was that the leaders within the movement seldom encouraged criticism of the movement and the party decision. ("Why Is the Left More Divided ..." 14).

Padatik is a movie about Mrinal Sen's middle period, but it never got the recognition it deserved. His hero questioned the ideology of the political party and leadership, which reflected the inner squabbles and contradiction of the then Communist party. Sen who was appreciated for his previous venture, Calcutta 71, was now called a traitor. This stigma haunted him for many years, even when years later the movie was screened in the Universities in the United States and Germany, pro-Left students jeered him. The absence of self-criticism and the prevalent selfcomplacency in the ruling Left, confused Sen. He often questioned himself if he was going in the right direction? According to him, radicalism demands going against the flow, against the authority, be it in West Bengal, or India, or anywhere around the world. This was all that Sen was trying to stand up for, and he did it in his way (Sen). Raghav Bandopadhyay's Communis too did not meet with acceptance and positive criticism. It was an elegy to the glorious urge for a revolution that had churned the whole society out of its inertia but could not manage more. It is not pessimistic in its worldview, but it offers a reality check to the leaders and their political parties. Bandopadhyay wrote this novel, after serving three years in jail. Being an enthusiastic youth, he too had plunged into the movement, imbibed with its revolutionary ideology. A firsthand experience of the movement, and contemplation during his imprisonment, allowed him 
to analyze the various dimensions of the truth. So, Communis, Shoishob, and Journal 70, written at various times in his career, explore the multifaceted nature of identity, ideology, and its subversion. Anirban Das while writing the introduction to 1970, containing both Communis and Journal 70, asserts, that Bandopadhyay establishes how the revolutionary project had seized to be different from the oppressive and dehumanizing structures that it had set out to fight. Journal 70 was an autobiographical account of Bandopadhyay's experience of the 1970s, written twentyfive years later. Bandopadhyay tries to situate the movement in the world Marxist Movement with its dogmatic doctrine and the immediate strategy of dominance. The paper intends to study the various aspects of the movement and the individuals involved in the movement. With the help of content analysis the paper tries to theorize the role of an intellectual within the movement, the position of women and other subalterns in this counter-narrative and it finally contextualizes the movement spatially in the power structures of the 1970s Kolkata. Using a text and a film, from a non-canonical author and a world-famous director respectively, the paper tries to bring into focus the subaltern narratives amidst the framed narrative of the movement.

\section{To be a "Communis"}

Revolutions liberate men, not just from social, economic, and political dominance, but also from the oppressive reality in which they exist by creating a consciousness of that reality. This consciousness is a cultural and historical process that is called "conscientization" (Friere). India developed a conscientization, during the freedom movement and in 1947 India awoke to life and freedom. However, the dream of freedom remained unfulfilled to millions of people, and the "comprador bureaucrat capitalist" (Banerjee 42), after ascension, fearing subordination reinstated a culture of silence. The nationwide crisis that followed was a transitional period: a 
counter-revolution where the intellectuals, mobilized the mass against the capitalist government. From a small group of intellectuals, this fragmented awareness seeped into the masses through various apparatuses. This awareness-driven methodology may also be manipulative in nature, creating false consciousness. According to Gramsci, all men are intellectuals however "not all men have in society the function of intellectuals" (115). The limited men who identify themselves as intellectuals are bestowed with several roles and responsibilities.

Said in his Representations of the Intellectuals writes-

There has been no major revolution in modern history without intellectuals; conversely, there has been no major counterrevolutionary movement without intellectuals. Intellectuals have been the fathers and mothers of movements... The intellectual does so based on universal principles: that all human beings are entitled to expect decent standards of behavior concerning freedom and justice from worldly powers or nations, and those deliberate or inadvertent violations of these standards need to be testified and fought against courageously (10-11).

However, the revolutionary agenda often becomes inconsistent, compromising its purpose when it becomes a victim of a fatalist concept of history. It tries to manipulate mechanically the "cannon fodder" to a future that the leadership knows a priori, but which it thinks the people are incapable of knowing. When revolutionary leadership places them on moral high ground and makes themselves unquestionable, they start becoming that which it had set out to subordinate. It starts denouncing whoever denounces it and proclaims the superiority of its ideology (Banerjee 271; Ray 176). The project aimed at creating an alternative reality settles into the existent inertia. Revolutionary movements, like reformists, cannot be static, for the dynamism in it is liberating, and it is life-giving and life-changing. Practicing, a methodology akin to the reformists 
subordinates the whole purpose of it. This reduces the movement to anarchy and a mad scramble for power and dominance. The idea of conscientization is to connect with the people, to exhibit love, confidence, and faith with the mass (Friere). As leaders and independent thinkers, intellectuals are equipped to resist and fight the stereotyping and consequently the death of genuine living things, so they would be expected to offer solidarity and effort. "If the thinker does not relate himself to the value of truth in political struggle, he cannot responsibly cope with the whole of live experience" (Mills 238). It is this absence of truth, solidarity, and effort which gradually became visible within the movement. Much like the reformists, the revolution started preferring the dead to the living, the future as a repetition of the past than engineering a new beginning, the frigid schematization rather than the emotion of living, pathological forms of love than real love, and slogans rather than challenges (Friere). The Naxalite Movement, like most Marxist movements in Asia, Africa, and Latin America, could not become the utopian biophilia that a revolutionary project should be; it ended up becoming necrophilic with its rigidity as the leaders became bureaucratic (Fromm 50). Ashim Chatterjee rightly asks- "Sacrifice of lives in battles is inevitable. But why wouldn't we have the courage to seriously reconsider whether it was necessary to sacrifice all the lives of heroes in Calcutta?" (quoted in Banerjee 199)

By the end of 1970 , the police had already categorized the urban guerrillas into three groups. Firstly, the completely criminal lumpenproletariat; secondly students and working class, who were not politically furnished but jumped into the movement out of frustration or for the zest of revolution, and lastly the ideologically equipped petty bourgeois, who posed the real threat (Banerjee). So in Communis, Shona, Montu, Biru, Nibaron, Shuku, Bijoy and Buro belong to the second category along with Biman from Padatik; they were the cannon-fodders, without the ability to think independently and question the ideology and its subversion by the leadership. 
Gora, AB, Narayan in Communis, and Sumit and Nikhil are of the third category. Nibaron, Buro, and Bijoy are expelled workers of locked-down factories and more valuable to the party than the petty bourgeoisies. Shona, Montu, and Biru are reckless, independent, bright students, with varying degrees of passion and consciousness about the struggle. They are not the monstrous criminals that police or media represented them to be; they are dreamers on a revolutionary mission. Slogans from their pen ended up being songs and poems. They are consumed by the passion of the revolution; they sincerely felt that violence, terror, and annihilation could subordinate the administration and bring about the desired change. Nibaron, Buro, and Bijoy had faced the class enemy from close quarters; their frustration did not allow them the patience to reconsider the misdirectedness of their violence. Blindly, they follow the leader who promised them if not a job, then at least revenge for their sufferings. Sumit says that he too was like Biman at a time, unable to think and criticize, but with time he had learned to generate his line of thoughts. But at the cannon-fodder level, any form of question is considered a result of frustration or defeatism. Also, any questions raised by them are not entertained by the leaders at every level, destroying the very possibility of consciousness-raising. It is only when he is cut off from the party that Sumit learns to think clearly. It is also interesting to note, that in the movie, Nikhil the party leader, employs two workers for printing the party pamphlets; his behavior with them and their deplorable work condition and extreme work hours that reduce them to a machine is no different from the capitalist landowners or industrialists. A binding thought of these revolutionaries was the glory of martyrdom. Exterminated comrades were celebrated through actions (R. Bandopadhyay) in the locality. There was also a strict guideline to be followed in the jail. To be a communist in jail is not to take any help from the parliamentary laws and lawyers, nor avail the privileges of a political prisoner, to distinguish themselves from the revisionists. 
Jailbreaks were considered the most glorious of acts. What we see here is how even when the revolution was aimed at breaking free from existing social structures, they, in turn, created new hierarchies and structures, which were not very different from the old ones.

\section{A Gendered Perspective}

Khokan Majumdar in his interview with Sinha Roy notes regarding the significance of women's participation in the movement:

I think the essence of women's participation in the Naxalbari movement . . Naxalbari movement has had a worldwide exposure; the history has been recorded; several plays, novels, and academic studies have been written [. . .] most of them either do not contain any reference or very little information about women's role in the movement . . in my view without women's active participation and support Naxalbari perhaps would not have become Naxalbari as we know it today. ("Contesting Calcutta Canons..." 167)

Sinha Roy (Gender and Radical Politics in India; "Magic Moments of Struggle;" Speaking Silence...") and Srila Roy (Remembering Revolution Gender...; "The Ethical Ambivalence of Resistant Violence;" "The Grey Zone") in their works have studied the marginalized position of women within the Naxalite movement. Other leaders, including Kanu Sanyal ${ }^{2}$ and Ashim Chatterje $^{3}$ have confirmed that there was gender discrimination and insensitivity within the movement. Since they lacked access to education and were already relegated to secondary status in society, they never rose to higher ranks within the party leadership. They acknowledged that the party faced structural problems and the leaders were unaware of the discrimination and baseness faced by the women comrades. There was a gendered division of labor and women were marginalized from key revolutionary responsibilities; at the same time, women were still vulnerable to aggression, sexual violence, and everyday risks within the movement and even 
more when they were arrested and put in jail. This lack of concern for women within the movement is also part of "Left traditionalism" (Brown 458; Roy 189) and has been a common phenomenon in many other progressive Left-wing movements. (Custers; Kannabiran and Kannabiran; Kannabiran and Lalitha; Lalita)

In the survey conducted by Shilpi Mitra in Padatik, she tries to find out, with the change in the social and political sphere, if there was any change in the relationship between men and women. Her target population was middle-class educated and working women, directly or indirectly related to various political movements. All of them agreed, like the social and political arena, there was no revolutionary change in the position of women. There was a certain degree of liberty in the fields of education and career, but that was essentially under some male supervision, be it the father, husband, or even the son. More women participated in public activities; they could be seen in public transport, political gatherings, theatres, and hospitals. There was a consciousness among women from different walks about the inconsistency in the gender positions and roles, thereby cultivating in them a sense of self-respect. They were no more the "privileged" Nora of A Doll's House. There was also a realization, that once a woman entered the labor market she would be commodified, following a change in her identity. In the capitalist society, the ideas of the ruling class are the ruling ideas, women being the second sex, thus always assumed the position of the dominated. Another interesting aspect that comes up in this survey is how women participate in political activities. A widowed woman can participate in movements with much more enthusiasm, than a woman under the supervision of a male member. In the novel we see Minu actively joining the movement only after Shona dies; Shilpi Mitra in the movie, though a distant sympathizer of the movement is a divorcee. Gora wonders whether Minu joins the movement to escape the grief of losing Shona, or is it a genuine revolutionary 
zeal. Mrs. Mitra had lost her brother in the movement, which had drawn her into the movement, even though she belonged to the upper-class bourgeoisie. Other woman characters in the novel like Bijoy's wife or Minati, Narayan's wife participate in the movement only in the absence of their husbands. While interviewing fairly recognized local leaders of the movement, Sinha Roy noted that the dominant memory of these male leaders did not register the female presence as such "and those who joined merely followed their male lovers into the movement" ("Contesting Calcutta Canons..." 164). We see there is a similar lack of representation of women characters who participated in the movement on account of poverty, previous political association, and coercion by male members of the family.

When Minu comes to Gora and AB, she is compared to Comrade Nirmala and her strength and sincerity are questioned. The movement was essentially masculine in nature. Women were accommodated in it only when there were not enough men to continue the struggle or for technical jobs only. Only a few women leaders remain registered in dominant memory like Comrade Nirmala, the rest of them have been largely ignored and marginalized from a public account. Srila Roy writes regarding political labor and gender performance (187-204), that once within the movement, women were generally assigned technical jobs like transporting papers, arms, and information; they were generally not involved in organizational works like recruiting people, campaigning, or forming squads. There were only a few women in local committees and none in senior leadership positions. Only a few women participated in semi terrorist acts like large-scale robberies, stealing arms, desecrating public institutions, disrupting classes and examinations, and throwing bombs. As state repression grew and as more members were lost, women gradually participated in armed jailbreaks and the annihilation of class enemies. ("The Everyday Life of the Revolution"). Works by Srila Roy and Sinha Roy have brought to attention 
the marginalization of women's participation in the movement; besides Krishna Bandyopadhyay's autobiographical account has also depicted the experience of women leaders in the movement. The representation of Minu, Minati, Shilpi, and others in these two texts further acknowledge their accounts. The movement to have been a successful revolution should have been gender-sensitive and truly and should have demolished the existing hierarchy based on gender, caste, and class.

\section{Calcutta-A Problem City}

Sen and Bandopadhyay's narratologies were a reflection of the violence and misery that had engulfed the city. The Naxalite uprising was ignited in the little village called Naxalbari in the Darjeeling district of West Bengal (Mohanty). However, as the movement escalated Calcutta became the urban center of the struggle, as more and more urban intellectuals participated in the movement (Mohanty). There was increasing unemployment, poverty, and dissatisfaction with the system. Calcutta became the heartland for all forms of struggle. Sen starts the movie with a quote both critiquing and eulogizing his city:

Every time I return to Calcutta, I feel it must be surely impossible that it can continue much longer than this. Yet it always does. An interval of a year makes the visual impact more painful, the squalor is more squalid, the poverty more militant, the despair more desperate. Every time I return to Calcutta, I find it an intimidating and even infernal city, unredeemed and probably doomed (Padatik).

Both Sen and Bandopadhyay introduce their protagonists in their narratives as they narrowly escape their enemies. Through vivid imagery Bandopadhyay then creates the claustrophobic world of subalternity, while sometimes sunlight is considered "untouchable" and "anaemic;" at 
other times the hovels in a slum are compared to pieces of meat in a "kebab" (R. Bandopadhyay) which later we see is the food of the comrades in hiding. Sen uses the interesting imagery of a clock, which functions only when kept facing down, analogous to the social structure. Sumit, the protagonist of Sen's movie is sheltered in a multi-storied building, in Park Street, decorated with tasteful paintings, exotic masks, and money plants. Sumit calls this a "fancy hell" (Padatik). The characters of Bandopadhyay's novel take shelter on the third floor of the building which is the CIT building, located in Beleghata. The CIT Building is far away from the populous slums, where the only sound that one can hear is the mechanical noise of buses passing by during the day, and alcoholics singing at night. These high-rise shelters are conduits of escape from the problems of the city which allows the protagonists to think out loud on sleepless nights, or sitting in an overflowing bathtub.

The Police operations in 1970 divided the city into four zones of guerrilla operations. The North and Central Calcutta- with intricate and inaccessible lanes, by-lanes, and blind-lanes -were called "liberated zones" or muktanchal. Here they employed the local lumpenproletariat to hunt down the Naxalites. The Eastern suburb along the railway canals was prone to smuggling, wagon breaking and other extra-legal activities also became safe houses for the Naxalites. The industrial area too, with working-class slums, was a haven for the guerrillas. The Southern part of the city was home to jobless and unsettled refugees from East Bengal, who were keen on militant political action (Banerjee). Gora, Bandopadhyay's protagonist, walks us through all these parts of the city, during his actions and errands.

The three primary crises which the revolutionary student youth movement identified in Deshabrati, published on $20^{\text {th }}$ February 1969 , were "food, employment, education and culture" (Banerjee). It is against these issues that the urban youth declared war. Sen at the onset itself lists 
the crisis that engulfed the city in particular and the nation in general. "Kerosene disappears from the market, Thousands of ghost ration cards seized by police, Death by starvation, Examinations disrupted, Rival Unions Clash in labor belts (...) The government pledged to restore law and order" (Padatik). A baby food advertisement that Shilpi designs addresses issues like starvation and adulteration of food materials. It is highly ironic how a capitalist company owner uses prevalent social issues to sell their product, and it is designed by a party sympathizer. It is not possible for someone who cannot afford a square meal to buy baby foods, but the images of babies suffering from malnutrition and their concerned mothers are used to play on the sympathy of middle-class buyers. Fuel and energy were scarce, resulting in price rise; but words, promises, tea, and cigarettes became cheaper. Walls were filled with graffiti, with ideologies overlapping each other and white paint always trying to subordinate the other. Political gatherings promised food, which attracted people from far and near, but that led to nothing but noise pollution. Tea stalls became the popular place for political deliberations where thoughts and cigarettes were smoked up in the air, as factories and industries were shut down in every corner of the city.

The prevailing education system in India in the seventies was essentially colonial in nature, constructed to offer jobs, avoid class struggles or prevent any revolutionary war. A nonviolent picture of the independent movement was painted before the students through school, college, and university curriculum. Also, every attempt was made to keep alive the class and caste hegemony, making the right use of the opportunity to increase the gulf between the city and the village. The students instead of trying to reform the educational and cultural setup misdirected their violence. While breaking statues of bourgeois, political and social reformers do send a message of revolution, but more often than not, it was misdirected and lacked ideological motive. The images of "action" terrorized the masses and created "Naxalphobia" (Banerjee). The 
party initially supported this manifestation of iconoclasm but with time, there was growing skepticism among party leaders about the fruitfulness of such mass destruction. Montu and Shona among others, of Communis debate over whether it is justified to destroy libraries, schools, and other bourgeois educational setups. One major question that rose about the motive of the majority of iconoclasts of Calcutta in 1970 was, whether it was intense class hatred, born of years of oppression, sustained by deep-rooted anger, and directed against symbols of political, social, and economic oppression, as was with the peasants? Or was it a sense of insecurity with the lack of jobs and futile university certificates that made schools, colleges, and examinations a soft target of their violence? (Banerjee). There was no violence aimed against the clubs, bars, restaurants, and discotheques of Park Street and Chowringhee. We cannot miss the amazement in the eyes of Sumit and Biman as they step into the fancy world of Mrs. Mitra even though they criticize it.

Sen and Bandopadhyay through their art were thinking out loud about the future of the movement. Although they shared the same theme, their presentation was very much different from each other. Most of Sen's character spoke in unaccented and refined Bengali, while Bandopadhyay throughout Communis uses an accented and often subaltern mispronunciation of Bengali words, which at times becomes incomprehensible even to native speakers. This incomprehensibility creates a sense of discomfort, which introduces the readers to the life and living of these Naxalites. Since the writer cannot use images and visual tools; his language replicates the grotesque world of the revolutionaries.

\section{The Unanswered Questions: Towards a Conclusion}


Biman asks Sumit, why is Sumit's father so opposed to Sumit's participation in the movement even when he was a revolutionary leader during India's freedom movement. Sumit asks Nikhil in particular and the party in general, who their enemies and friends are, for whom, and with whom is the movement. If it is indeed, for the workers, peasants, and middle-class have they been successfully involved and mobilized within the movement-and not coerced into it. The party not only refuses to answer the questions raised by Sumit but also doubts his integrity and expels him. Gora too questions the leadership, not just their ideology but also their nature. While $\mathrm{AB}$ with rising power had become fascist by nature, Narayan had continued being the friend, philosopher, and guide. Comparing both of them, Gora asks whether it is necessary to be dictatorial with increasing power or is there an alternative. These questions hang in the "vacuum" (Padatik) like the movement itself. Sumit's father was a freedom fighter, one who had been to jail. In his youth he had been invigorated by the accounts of the Bolshevik Revolution and fought against a foreign rule to free his motherland; it was respectable to do so. In an independent state, challenging governmental structures is considered anti-national, an act of betrayal, which he was not ready to commit as long as he had a respectable job. It was difficult for him to accept that a peaceful transition to Winter Palace could not be possible. But Sumit and Gora had been born and brought up in the era of revolutions. There's was a generation that refused to cooperate with the faded dream of the revisionists. "Political power grows out of the barrel of a gun!” (Zedong 224). Without any clear political agenda, the class enemy could not be precisely defined. So, the red terror was directed indiscriminately against traffic constables, plain-clothes policemen, and police officers, personnel of Para-military forces, small shopkeepers, other businessmen, doctors, and teachers. The counter-offensive too killed many innocent youths. The message of defying death and embracing martyrdom, though very 
romantic, was in no sense advisable for the movement, at such an initial stage. The number of annihilation had reached almost 200, in West Bengal alone, in 1970, but the number of martyrs among the revolutionaries was much higher (Banerjee 265-314). Another equally important debate was, the revolutionaries were expecting too much in a too short time; although they had not done enough to develop a base among the working class or political consciousness among the peasants. There were not enough mobilizations of the prospective support groups. So a uniform action was not accepted uniformly at all places. The comrades themselves became skeptical about the future of the movement.

A revolution is a critical and continuous process. It does not end with a huge gathering, where the party flag proudly flutters in the air and people live happily ever after that, as the comrades fantasize. Revolution is an amalgamation of action and reflection. It is a journey towards the "heaven of freedom" (Tagore 28). The movement of the 1970s failed because it could not radically distinguish itself from the reformist course of action. Sen and Bandopadhyay, both have been criticized for having washed their dirty laundry in the public. It is only when we look back we realize that they had done exactly what the leaders of the movements should have done then. An objective evaluation of the movement would have in no way put it in crisis; rather a lack of it did.

\section{Endnotes:}

1. Interview conducted by Mallarika Sinha Roy of Khokan Majumdar in Barajharujote village, Darjeeling district, October 2004; Excerpt from Roy, Mallarika Sinha. "Contesting Calcutta Canons: Issues of Gender and Mofussil in the Naxalbari Movement in West Bengal (1967-1975).” 
2. Interview conducted by Mallarika Sinha Roy of Kanu Sanyal in Hatighisha village, Darjeeling district, October 2004; Roy, Mallarika Sinha. “Contesting Calcutta Canons: Issues of Gender and Mofussil in the Naxalbari Movement in West Bengal (19671975).”

3. Interview conducted by Mallarika Sinha Roy of Ashim Chatterjee in Calcutta, December 2004; Roy, Mallarika Sinha. “Contesting Calcutta Canons: Issues of Gender and Mofussil in the Naxalbari Movement in West Bengal (1967-1975).”

\section{Works Cited}

Bandopadhyay, Krishna. “Abirata Larai” [Relentless Struggle]. Khonj Ekhon, No I. 2001.

Bandopadhyay, Raghav. Communis. Chorchapod, 1975.

Banerjee, Sumanta. India's Simmering Revolution. Zed Book Ltd, 1984, pp. 172-214

Banerjee, Sumanta. "Why Is the Left More Divided Than the Right?" Economic and Political Weekly, Vol. 48, No. 38, 2013, pp. 14-16.

Brown, Wendy (2003) "Resisting Left Melancholia.” Loss: The Politics of Mourning. Edited by David L. Eng and David Kazanjian. University of California Press, pp. 458-465.

Chatterjee, Dhritiman. actor. Padatik, Mrinal Sen Productions, 1973.

Custers, Peter. Women in Tebhaga uprising: Rural poor women and revolutionary leadership. Naya Prokash, 1987.

Friere, Paulo. "Cultural Action and Conscientization." Cultural Action for Freedom, Harvard Educational Review, 1970, pp. 39-68. 
Foucault, M. "Preface." Anti-Oedipus: Capitalism and Schizophrenia, University of Minnesota Press, 1984.

Fromm, Erich. The Heart of Man. Harper \& Row, 1964.

Gramsci, Antonio. "The Intellectuals.” An Anthology of Western Marxism, Oxford UP, 1989, pp. 113-119.

Kannabiran, K. \& V. Kannabiran. De-Eroticising Assault: Essays on Modesty, Honour and Power. Stree, 2002.

Kannabiran, V. \& K. Lalitha. “That Magic Time: Women in the Telengana People's Struggle.” Recasting Women: Essays in Colonial History. Edited by K. Sangari \& S. Vaid, Kali, 1989.

Mazumdar, Charu. "Party's Call to the Youth and Students." Communist Party of India (MarxistLeninist). http://cpiml.org/library/charu-mazumdar-collected-writings/formation-ofcommunist-party-of-india-marxist-leninist-22-april-1969/partys-call-to-the-youth-andstudents/ Accessed 26 May 2021.

Mills, C. Wright. "The Powerless People: The Social Rôle of the Intellectual.” Bulletin of the American Association of University Professors (1915-1955), Vol. 31, No. 2, 1945, pp. 231243. https://www.jstor.org/stable/i40007888. Accessed 17 June 2021.

Mohanty, Manoranjan. “The Environment of Revolt.” Revolutionary Violence: A Study of the Maoist Movement in India. Sterling Publishers Pvt. Ltd., 1977, pp. 31-59

Padatik, Directed by Mrinal Sen. Mrinal Sen Productions, 1973.

Ray, Rabindra. The Naxalites and Their Ideology. Oxford University Press, 1988. 
Roy, Mallarika Sinha. “Contesting Calcutta Canons: Issues of Gender and Mofussil in the Naxalbari Movement in West Bengal (1967-1975).” Contemporary South Asia, Vol. 17, No. 2, 2009, pp. 159-174., https://doi.org/10.1080/09584930902834178

Roy, Mallarika Sinha. Gender and Radical Politics in India. Routledge, 2010, pp. 1-24. https://doi.org/10.4324/9780203845950

Roy, Mallarika Sinha. "Magic Moments of Struggle.” Indian Journal of Gender Studies, Vol. 16, No. 2, 2009, pp. 205-232. https://doi.org/10.1177/097152150901600203.

Roy, Mallarika Sinha. "Speaking Silence: Narrative of Gender in the Historiography of the Naxalbari Movement in West Bengal (1967-75)." Journal of South Asian Development, Vol. 1, No. 2, 2006, pp. 207-230. https://doi.org/10.1177/097317410600100203.

Roy, Srila. Remembering Revolution Gender, Violence, and Subjectivity in India's Naxalbari Movement. Oxford University Press, 2013.

Roy, Srila. “The Ethical Ambivalence of Resistant Violence: Notes from Postcolonial South Asia." Feminist Review, Vol. 91, No. 1, 2009, pp. 135-153. https://doi.org/10.1057/fr.2008.53.

Roy, Srila. "The Everyday Life of the Revolution." South Asia Research, Vol. 27, No. 2, 2007, pp. 187-204., https://doi.org/10.1177/026272800702700204.

Roy, Srila. “The Grey Zone: The 'Ordinary' Violence of Extraordinary Times.” Journal of the Royal Anthropological Institute, Vol. 14, No. 2, 2008, pp. 316-333. https://doi.org/10.1111/j.1467-9655.2008.00503.x.

Said, Edward. "Representations of the Intellectuals." Representations of the Intellectuals: The 1993 Reith Lecture Series, Vintage Books, 1996, pp. 3-23.

Sen, Mrinal. Montage: Life, Politics, Cinema. Seagull Books, 1999. 
K., Lalita, et al. We were making history: Life stories of women in the Telangana people's struggle. Zed Books, 1989.

Tagore, Rabindranath. "Where the Mind is Without Fear." Gitanjali (Song Offerings), The Macmillan Company, 1915, pp. 27-28.

Zedong, Mao. "Problems of War Strategy." Selected Works, Vol. II, Foreign Language Press, 1965.

\section{Bionote:}

Pratyusha Pramanik is currently a Senior Research Fellow in the Department of Humanistic Studies, Indian Institute of Technology (BHU) Varanasi, India. She has done her post-graduation in English Literature from Banaras Hindu University; and her graduation from Bethune College, University of Calcutta. Her works have appeared on various online portals like Feminism in India, Borderless Journal, and Café Dissensus. Her areas of interest include Gender Studies, Film \& Literature, and Indian Writing in English. She is a Teaching Assistant in her institute and engages students in several elective courses offered by her Department. She has also been a Teaching Assistant at an NPTEL Online Certification course from February-April 2021. She can be reached at praty1995@gmail.com

ORCID ID: https://orcid.org/0000-0001-8854-5504

\section{Open Access:}

This article is distributed under the terms of the Attribution-NonCommercial 4.0 International (CC BY-NC 4.0) (https://creativecommons.org/licenses/by/4.0/) which permits any use, reproduction and distribution of the work without further permission provided the original work is attributed as specified on the Transcript: An e-Journal of Literary and Cultural Studies. For more information log on to http://thetranscript.in/

\section{Conflict of Interest Declaration:}

The author declared no potential conflicts of interest about the research, authorship, and publication of this article.

(C) Author 